DRUŠ. ISTRAŽ. ZAGREB

GOD. 22 (2013),

BR. 2

STR. 379-389

mizam i kult minimalne varijacije. Cilj nove ljevice, po autorovu mišljenju, trebao bi biti podvrgavanje države općoj volji. To uključuje oživljavanje koncepta opće volje i moderniziranje ideje o javnom prostoru. Kriza je pokazala da su spekulacije da bi kapitalizam mogao biti na rubu propasti neutemeljene. Bankovni spasilački paketi bili su utvrđivanje ustrajavanja da nema alternative. Nova ljevica mogla bi početi dograđivati na želje koje je neoliberalizam stvarao, a koje nije mogao zadovoljiti, npr. masovno smanjivanje birokracije. Potrebna je, misli autor, nova borba za rad i tko ga nadzire, utvrđivanje autonomije radnika. Sama opresivna prodornost kapitalističkog realizma znači da čak tračci alternativnih političkih i ekonomskih mogućnosti mogu imati nerazmjerno velik učinak.

Autor primjerima iz svakodnevnoga života i iz popularne kulture portretira naše sadašnje stanje. Kapitalistički realizam pokazuje se kao sveprožimajuće ozračje, kao nevidljiva barijera koja ograničuje naše mišljenje i djelovanje. Obuhvaćeni takvom imanentnom barijerom, postavlja se pitanje odakle može doći djelotvoran otpor. Fisher nam nudi odgovor: "kapitalistički realizam može jedino biti ugrožen ako ga se prikaže nedosljednim ili neodrživim", tj. ako se prikaže kako realizam nije zapravo realizam u svojim postavkama. Ono što nam nudi jest prostor izranjanja iz uljuljanoga sna o neporecivosti realizma koji nas okružuje. Prvi je korak da se počne razmišljati o drugačijem tipu realizma. Prema tome, doprinos ove knjige ne mjeri se samo $u$ identificiranju stanja kasnoga kapitalizma nego i u pozivu na identificiranje mogućnosti drugačijih stanja.

Danijel Baturina

\section{doi:10.5559/di.22.2.11 \\ Linda Steg, Agnes E. van den Berg i Judith de Groot (ur.) ENVIRONMENTAL PSYCHOLOGY: AN INTRODUCTION}

British Psychological Society i John Wiley \& Sons, West Sussex, UK, 2012., 376 str.

U ovom udžbeniku ekološke psihologije više od 50 autora u 27 poglavlja daje prikaz trenutačnoga stanja na području ekološke psihologije. Ekološka psihologija najčešće se definira kao disciplina psihologije koja se bavi proučavanjem interakcije između pojedinaca i njihove prirodne i izgrađene okoline. Iako predstavlja relativno mladu disciplinu, u proteklom desetljeću doživljava jak razvoj zbog povećanog interesa za pitanje održivog razvoja.

Na početku knjige daje se povijesni pregled razvoja područja, od perioda neposredno nakon Drugog svjetskog rata, kada je žarište ekološke psihologije bilo usmjereno na istraživanje utjecaja izgrađene okoline na ljudsko ponašanje i doživljavanje, preko 1960-ih godina, kada je žarište istraživanja bilo određeno razvojem svijesti o ekološkim problemima, pa sve do ekološke psihologije 21. stoljeća, kada je teme i područje istraživanja uvelike odredio koncept održivog razvoja.

Knjiga je podijeljena u tri dijela.

Prvi dio bavi se utjecajem okoliša na ljudsko ponašanje i dobrobit te započinje klasičnim temama iz ekološke psihologije - percepcijom okolinskih opasnosti i okolinskim stresom. Nakon objašnjavanja uloge heuristika i pristranosti u procjeni okolinskih opasnosti, autorice se osvrću na individualne razlike $\mathrm{u}$ vrijednostima i moralu koje određuju percepciju okolinskih opasnosti, kao i razlike u emocionalnom doživljavanju koje se javljaju kao posljedica, ali i uzrok, percepcije rizika. Poglavlje 
BR. 2

STR. 379-389

o stresu započinje pregledom teorija stresa, a kasnije se opisuju fiziološke i psihološke posljedice glavnih okolinskih stresora, uz navođenje empirijskih dokaza prema kojima kronična izloženost okolinskim stresorima, za razliku od akutne, dovodi do povećanja fizioloških (adrenalin, kortizol, krvni tlak) i psiholoških (negativne emocije i uzrujanost) indikatora stresa. Jedno poglavlje posvećeno je istraživanjima vizualne procjene i percepcije krajolika, koja svojim spoznajama mogu pridonijeti zaštiti krajolika i smanjenju daljnjeg uništavanja krajolika, koje je posebno izraženo zbog povećane urbanizacije. Dva poglavlja posvećena su zdravstvenim koristima prirode. Od toga prvo daje pregled literature koja upućuje na to da kontakt s prirodom - i pacijenata i široke populacije - dovodi do boljih rezultata na brojnim indikatorima zdravlja, dok drugo daje pregled već ustaljenih teorija, poput teorije oporavka od stresa i teorije obnove pažnje, ali se osvrće i na novija teorijska tumačenja koja restorativni učinak kontakta s prirodom objašnjavaju teorijom perceptivne fluentnosti, povezanošću s prirodom i konceptom mikro-restauracije. Dva poglavlja posvećena su kvaliteti života. Prvo se bavi pitanjem kvalitete života u urbanoj okolini, tj. kognitivnim, emocionalnim i ponašajnim odrednicama zadovoljstva životom u urbanom prostoru, uz opisivanje psihometrijskih alata koji se rabe za njihovo mjerenje. Drugo poglavlje posvećeno je odnosu individualne kvalitete života i održivog razvoja. Budući da održivi razvoj počiva na tri komponente (društvo, gospodarstvo i okoliš), među kojima treba uspostaviti ravnotežu, nužno je razviti kriterije održivosti za svaki od njih. Tako je, primjerice, količina emisije stakleničkih plinova kriterij za ekološku komponentu, stopa inflacije kriterij za ekonomsku komponentu, dok autorice smatraju da bi upravo kvaliteta života mogao biti kriterij za socijalnu komponentu na individualnoj razini. U poglavlju o pristupima dizajniranju izgrađenih prostora govori se o suradnji ekoloških psihologa i arhitekata u dizajniranju prostora za život koji zadovoljava potrebe korisnika stambenih prostora i pozitivno utječe na kvalitetu njihovih života. Dva poglavlja posvećena su ambivalentnim emocijama i mislima koje se javljaju u kontaktu ljudi s nepripitomljenom florom i faunom. Pretpostavlja se da se u osnovi straha od divljine nalazi briga za vlastitu egzistenciju, dok je odnos čovjeka prema nepripitomljenoj fauni određen dvjema vrijednosnim orijentacijama - dominacijom i uzajamnošću. Zadnje poglavlje u prvom dijelu posvećeno je istraživanjima znakova u okolini i njihovoj ulozi u predstavljanju ekološkoga ponašanja.

Drugi dio knjige bavi se faktorima koji utječu na ekološko ponašanje i započinje definiranjem ekološkoga ponašanja te razmatranjem problematike mjerenja i konceptualizacije ekološkoga ponašanja. Sljedeća četiri poglavlja progovaraju o ulozi vrijednosti, socijalnih normi, emocija i konflikata između individualnih i kolektivnih interesa kao osnovnim odrednicama ekološkoga ponašanja. U poglavlju o vrijednostima iznose se nove spoznaje o ulozi biosfernih vrijednosti kao važnoga prediktora ekološkoga ponašanja, dok se u poglavlju o normama piše o ulozi normi u razumijevanju i promjeni ponašanja u smjeru veće održivosti, s osvrtom na salijentnost normi, veličinu referentne grupe, osobne norme i konflikt između inferencijalne i deskriptivne norme kao važne moderatore utjecaja normi. Sljedeće poglavlje progovara o tome kako je u proučavanju ekološkoga ponašanja nužno uzeti u obzir emocionalne i simboličke elemente, poput vlastita identiteta i statusa. Jedno poglavlje posvećeno je razmatranju faktora koji određuju hoće li pojedinci u situacijama konflikata između individualnih i kolek- 
tivnih interesa izabrati djelovati u vlastitu interesu ili za opće dobro, a objašnjenja se temelje prije svega na teoriji pohlepe-efikasnosti-poštenja. Poglavlje o glavnim teoretskim modelima za objašnjavanje ekološkoga ponašanja objedinjuje spoznaje iz prethodnih poglavlja, prikazujući četiri prevladavajuća modela - teoriju planiranoga ponašanja, model aktivacije normi, teoriju vrijednosti-vjerovanja-normi i teoriju uokvirivanja ciljeva. Zadnje poglavlje $u$ drugom dijelu knjige bavi se ulogom navika u objašnjenju ekološkoga ponašanja.

Treći dio knjige opisuje strategije poticanja ekološkoga ponašanja. U prvom poglavlju razmatra se pet informacijskih strategija za poticanje ekološkog ponašanja (pružanje informacija, postavljanje ciljeva, obvezivanje te upotreba podsjetnika i povratnih informacija) i navode se njihove glavne prednosti i nedostaci, primjeri uspješno korištenih i specifične situacije na koje je pojedina strategija primjenjiva. Poglavlje o poticanju ekološkoga ponašanja uz pomoć nagrada i kazni u početku razmatra glavna bihevioristička načela primjene nagrada i kazni za poticanje ponašanja, a u kasnijem dijelu upozorava na moguće negativne posljedice pribjegavanju novčanim nagradama za poticanje ekoloških ponašanja, poput potkopavanja osjećaja moralne obveze za izvođenje ekološkog ponašanja. U poglavlju o primjeni tehnologija za poticanje ekološkoga ponašanja ne govori se o tehnološkim inovacijama koje mogu smanjiti negativan utjecaj na okoliš ili o potrebi promjene primjene tehnologije na sadašnji način nego o tehnologiji pametnih sustava, koja je dizajnirana kako bi promijenila ljudsku kogniciju, stavove i ponašanje u smjeru veće održivosti. Primjenom tehnologije pametnih sustava mogu se primjenjivati principi soci- jalnog utjecaja, poput odobravanja ili normi, i na taj način utjecati na ponašanje korisnika te tehnologije. Imajući na umu da je za provođenje politika zaštite okoliša nužno imati podršku javnosti, u sljedećem poglavlju raspravlja se o individualnim i kolektivnim posljedicama uvođenja određenih programa, kao i o poštenju prilikom donošenja odluka kao glavnim individualnim odrednicama prihvaćanja javnih politika. Zadnja dva poglavlja u ovom dijelu govore o relativno novim temama na području ekološke psihologije. U poglavlju o procesima promjene razmatraju se teoretski modeli koji opisuju procese promjene ponašanja - što motivira ljude na promišljanje vlastita trenutačnog ponašanja, na promjenu ponašanja i slično. U poglavlju o simulaciji "socijalno-ekoloških sistema" riječ je o simulaciji (agent based modelling) kao novom računalnom alatu, barem u društvenim znanostima, za proučavanje kompleksnosti socijalnih okolina kojim se ispituje kako interakcija između pojedinaca, ali i između pojedinaca i okoline, dovodi do određenih ishoda. Simulacija omogućuje provođenje eksperimenata na hipotetskim problemima, koji uključuju kompleksne interakcije većeg broja ljudi, s velikim brojem individualnih razlika. Tako se, primjerice, može simulirati utjecaj određene edukativne kampanje na promjenu stava ili utjecaj socijalno-psiholoških varijabli na prihvaćanje uređaja za štednju vode.

Specifičnost ovog udžbenika upravo je posvećenost trendovima i perspektivama u razvoju ekološke psihologije. Usmjerenost na pozitivne odnose između pojedinaca i okoline jedan je od novih trendova u ekološkoj psihologiji. Ekološka psihologija u svojim se počecima uglavnom usredotočila na istraživanje negativnih utjecaja okoline na ljude (npr. utjecaj zbijenosti na stres) ili na negativne utjecaje čovjeka na okolinu (npr. pretjerana potrošnja energije) te na razvoj strategija za smanjenje negativnih utjecaja. Međutim, povećanjem interesa za pitanja održivosti dio istraživanja počeo se baviti poticanjem pozitivnih utjecaja okoline na čovjeka (zdravstve- 
ne koristi okoline) i okoline na čovjeka (poticanje ekološkoga ponašanja). Ovaj pozitivni trend oslikava se $\mathrm{u}$ temama u sva tri dijela knjige. Tako je u prvom dijelu knjige veći dio tema posvećen upravo pozitivnom utjecaju prirodne i izgrađene okoline na kvalitetu života, u drugom dijelu više se govori o odrednicama ekološki osviještenoga ponašanja, poput biosfernih vrijednosti, normi ili očekivanja pozitivnih emocija, dok se treći dio gotovo potpuno usmjerio prema tehnikama i strategijama za poticanje ekološki osviještenoga ponašanja.

Kao drugi bitan trend ističe se potreba za razvijanjem kompleksnijih integrativnih modela, jer jednostavni modeli ljudskoga ponašanja (poput odnosa buke i stresa) više nisu dostatni za razumijevanje i rješavanje kompleksnih društvenih problema. Javlja se potreba za razvojem integrativnih modela, poput teorije uokvirivanja ciljeva, koja objedinjuje teorije što se temelje na emocijama, racionalne teorije poput teorije planiranoga ponašanja, kao i teorija moralne odgovornosti, poput teorije vrijednosti-vjerovanja normi.

Budući da je velik dio istraživanja na području ekološke psihologije proveden u Americi i Zapadnoj Europi, te utoliko umanjuje mogućnost generalizacije nalaza na druge kulture, ova je knjiga doskočila i tom problemu, posvetivši jedno poglavlje stanju ekološke psihologije u Latinskoj Americi, a drugo poglavlje razvoju mjera, modela i strategija promjene ponašanja u nerazvijenim zemljama svijeta.

Urednice na kraju ističu da ovakvi novi trendovi postavljaju i nove izazove za integraciju poddisciplina unutar ekološke psihologije, ali i veću interdisciplinarnost u pristupu rješavanju problema. Također napominju da će psiholozi zainteresirani za ovo područje biti suočeni s potre- bom razvoja integrativnih modela $\mathrm{i}$ istraživačkih metoda, poput istraživanja implicitnih ekoloških stavova i vrijednosti, uključivanja "mekanih" mjera, poput emocija, u prevladavajuće modele ekološkoga ponašanja koji se temelje na racionalnom donošenju odluka, kao i značajnije uključivanje ekoloških tema u kolegije psihologije na fakultete te uključivanje psihologa u politički i društveno relevantne aktivnosti za zaštitu okoliša.

Knjiga je pisana jednostavnim znanstvenim jezikom, stoga je posebno preporučujem čitateljima koji se žele upoznati s područjem ekološke psihologije. Izvrsno bi poslužila i kao udžbenik za kolegije ekološke psihologije na preddiplomskim ili diplomskim studijima, jer daje pregled područja od njezina nastanka pa do ključnih recentnih istraživanja i osvrta na istraživačka pitanja na koja se tek očekuju odgovori. Na kraju svakoga poglavlja nalazi se rječnik ključnih pojmova, prijedlog literature za one koji žele znati više, kao i pitanja kojima čitatelj može provjeriti svoje znanje, dok je dio poglavlja obogaćen i praktičnim savjetima za primjenu spoznaja u zdravstvu, urbanom planiranju te planiranju i provedbi politika zaštite okoliša. Zbog svega navedenog siguran sam da će ova knjiga zadovoljiti potrebe i najzahtjevnijih čitatelja zainteresiranih za područje ekološke psihologije.

Vanja Međugorac 